\title{
Global Freshwater Resources: Soft-Path Solutions for the 21st Century
}

\section{Peter H. Gleick}

Twentieth-century water policies relied on the construction of massive infrastructure in the form of dams, aqueducts, pipelines, and complex centralized treatment plants to meet human demands. These facilities brought tremendous benefits to billions of people, but they also had serious and often unanticipated social, economical, and ecological costs. Many unsolved water problems remain, and past approaches no longer seem sufficient. A transition is under way to a "soft path" that complements centralized physical infrastructure with lower cost community-scale systems, decentralized and open decision-making, water markets and equitable pricing, application of efficient technology, and environmental protection.
The world is in the midst of a major transition in water resource development, management, and use. This transition is long overdue. The construction of massive infrastructure in the form of dams, aqueducts, pipelines, and complex centralized treatment plants dominated the 20th-century water agenda. This "hard path" approach brought tremendous benefits to billions of people, reduced the incidence of water-related diseases, expanded the generation of hydropower and irrigated agriculture, and moderated the risks of devastating floods and droughts.

But the hard path also had substantial, often unanticipated social, economic, and environ-

Pacific Institute for Studies in Development, Environment, and Security, Oakland, CA 94612, USA. mental costs. Tens of millions of people have been displaced from their homes by water projects over the past century, including more than 1 million whose villages are now being flooded by the reservoir behind the Three Gorges Dam in China (1). Twenty-seven percent of all North American freshwater fauna populations are now considered threatened with extinction (2), a trend mirrored elsewhere around the world. Adequate flows no longer reach the deltas of many rivers in average years, including the Nile, Huang He (Yellow), Amu Darya and Syr Darya, and Colorado, leading to nutrient depletion, loss of habitat for native fisheries, plummeting populations of birds, shoreline erosion, and adverse effects on local communities (3-5).

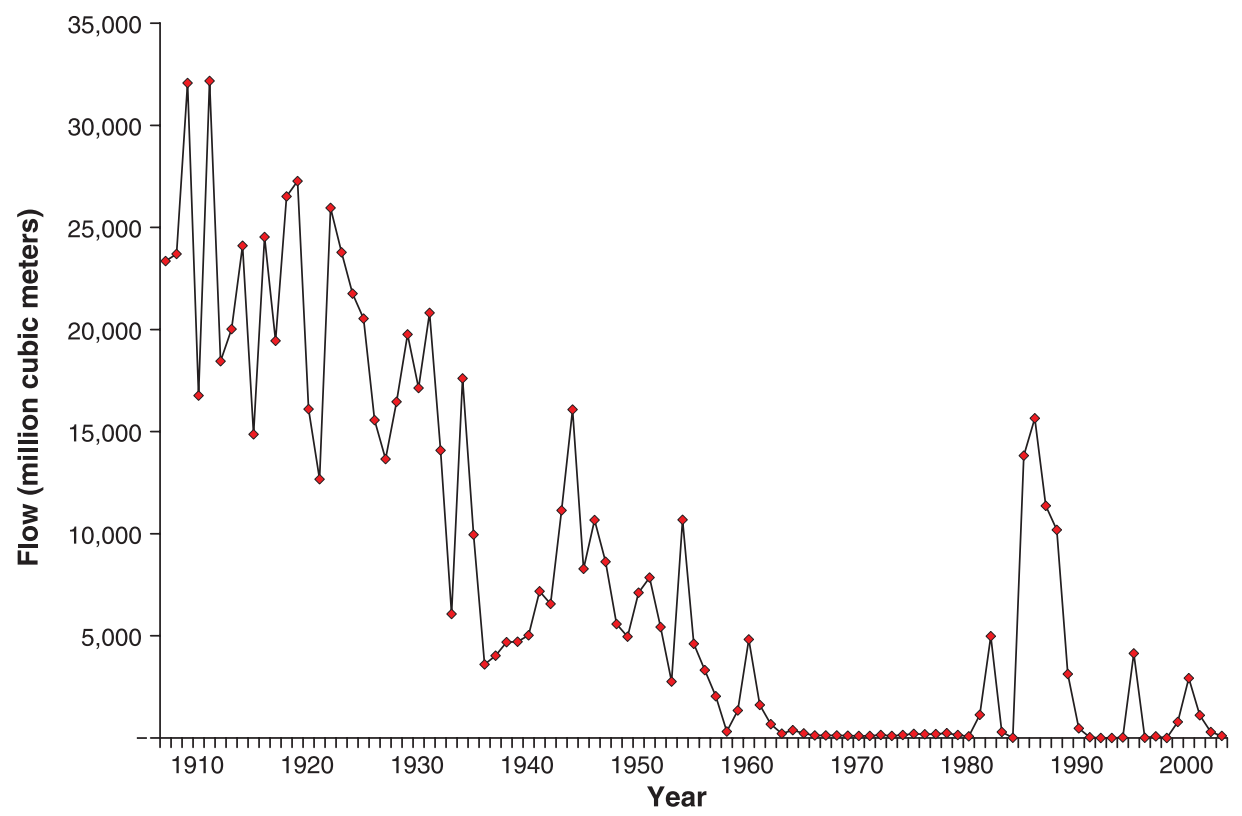

Fig. 1. Colorado river flows below all major dams and diversions, 1905 to 2001. Data are flows of the Colorado River as measured at U.S. Geological Survey Gage 09-5222, 35 km downstream from Morelos Dam. As shown, flows reaching the Colorado River delta have dropped to near zero in most years.
In arid regions of North America, the hard path for water was pursued especially aggressively. Massive dams and thousands of kilometers of aqueducts were built, permitting human withdrawal of much of the water formerly flowing to wetlands, deltas, and inland sinks, and hydrologic mastery over many watersheds. Since 1905, flows in the Colorado River have decreased markedly because seven states and Mexico withdraw the river's

Table 1. Aid to water supply and sanitation by donor (1996-2001).

\begin{tabular}{lcc} 
& \multicolumn{2}{c}{$\begin{array}{c}\text { Millions of U.S. } \\
\text { dollars }\end{array}$} \\
\cline { 2 - 3 } Country or & $1996-$ & $1999-$ \\
multilateral aid & 1998 & 2001 \\
organization & average & average
\end{tabular}

Australia $\quad 23 \quad 40$

Belgium

Canada

Denmark

Finland

France

Germany

Ireland

Italy

Japan

Luxembourg

Netherlands

New Zealand

Norway

Portugal

Spain

Sweden

Switzerland

United Kingdom

United States

Subtotal, countries

34

African Development

Fund

Asian Development Bank $\quad 150 \quad 88$

European Community $\quad-\quad 216$

International

$323 \quad 331$

Development

Association

Inter-American

Development Bank,

Special Operations

Fund

Subtotal, multilateral

575

730 organizations

Total water

3482

3098 


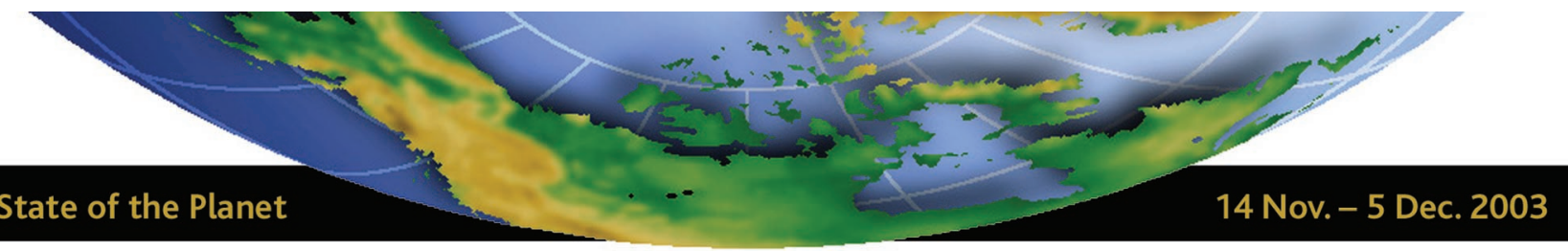

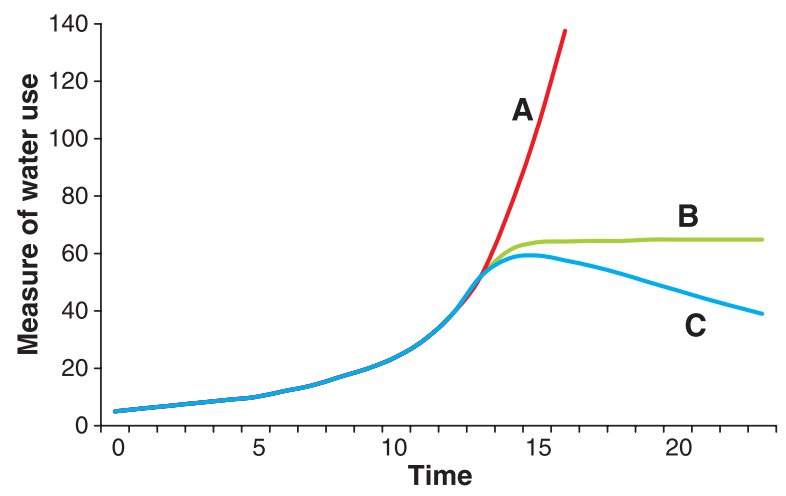

Fig. 2. Scenarios of future water use. The three curves represent continued exponential growth in demand (A), a leveling off of demand to steady state (B), and declining demand (C).

entire flow for agricultural and urban uses (Fig. 1). In most years no runoff reaches the river's delta in the Sea of Cortez. Yet calls for new dams in the western United States continue, predicated on the assumption that water problems there will finally be resolved with the construction of another increment of infrastructure (6).

The most serious unresolved water problem is the continued failure to meet basic human needs for water. More than 1 billion people worldwide lack access to safe drinking water; 2.4 billion-more people than lived on the planet in 1940 - lack access to adequate sanitation services $(7,8)$. The failure to satisfy basic water needs leads to hundreds of millions of cases of waterrelated diseases and 2 million to 5 million deaths annually (9).

Growing awareness of these and other complex challenges led the United Nations General Assembly to declare 2003 the International Year of Freshwater (10). Among the Millennium Development Goals adopted by the General Assembly are new efforts aimed at reducing by half the proportion of people unable to reach or afford safe drinking water and adequate sanitation services by 2015 (11). Without these goals, cumulative water-related deaths by 2020 are expected to be between 52 and 118 million deaths, mostly of children. Even if the water targets are reached, cumulative deaths by 2020 will be between 34 and 76 million. In comparison, cumulative early deaths from AIDS over the same period are projected to be 68 million $(12,13)$.

Unfortunately, the UN's water goals and solutions to other water problems are unlikely to be achieved, and 2075). given current levels of financial and political commitments. Despite growing awareness of water issues, international economic support for water projects of all kinds is marginal and declining. Official development assistance for water supply and sanitation projects from countries of the Organization for Economic Cooperation and Development (OECD) and the major international financial institutions has actually declined over the past few years ( Table 1), from $\$ 3.4$ billion per year (average from 1996 to 1998 ) to $\$ 3.0$ billion per year (average from 1999 to 2001). Moreover, those most in need receive the smallest amount of aid. Ten countries received about half of all water-related aid, while countries where less than $60 \%$ of the population has access to an improved water source received only $12 \%$ of the money (14).

New challenges further complicate approaches to solving water problems. Issues such as regional and international water conflicts (15), the dependence of many regions on unsustainable groundwater use (16), the growing threat of anthropogenic climate change (17), and our declining capacity to monitor critical aspects of the global water balance (18) are all inadequately addressed by water planners and policymakers. If these challenges are to be met within ecological, financial, and social constraints, new approaches are needed.

\section{0th-Century Water Policy and Planning}

The predominant focus of water planners and managers has been identifying and meeting growing human demands for water. Their principal tools have been long-range demand projections and the construction of tens of thousands of large facilities for storing, moving, and treating water. The long construction times and high capital costs of water infrastructure require that planners try to make long-term forecasts and projections of demand. Yet these are fraught with uncertainty. Three basic futures are possible: (i) exponential growth in water demand as populations and economies grow, (ii) a slowing of demand growth until it reaches a steady state, and (iii) slowing and ultimately a reversal of demand (Fig. 2). Reviewing the last several

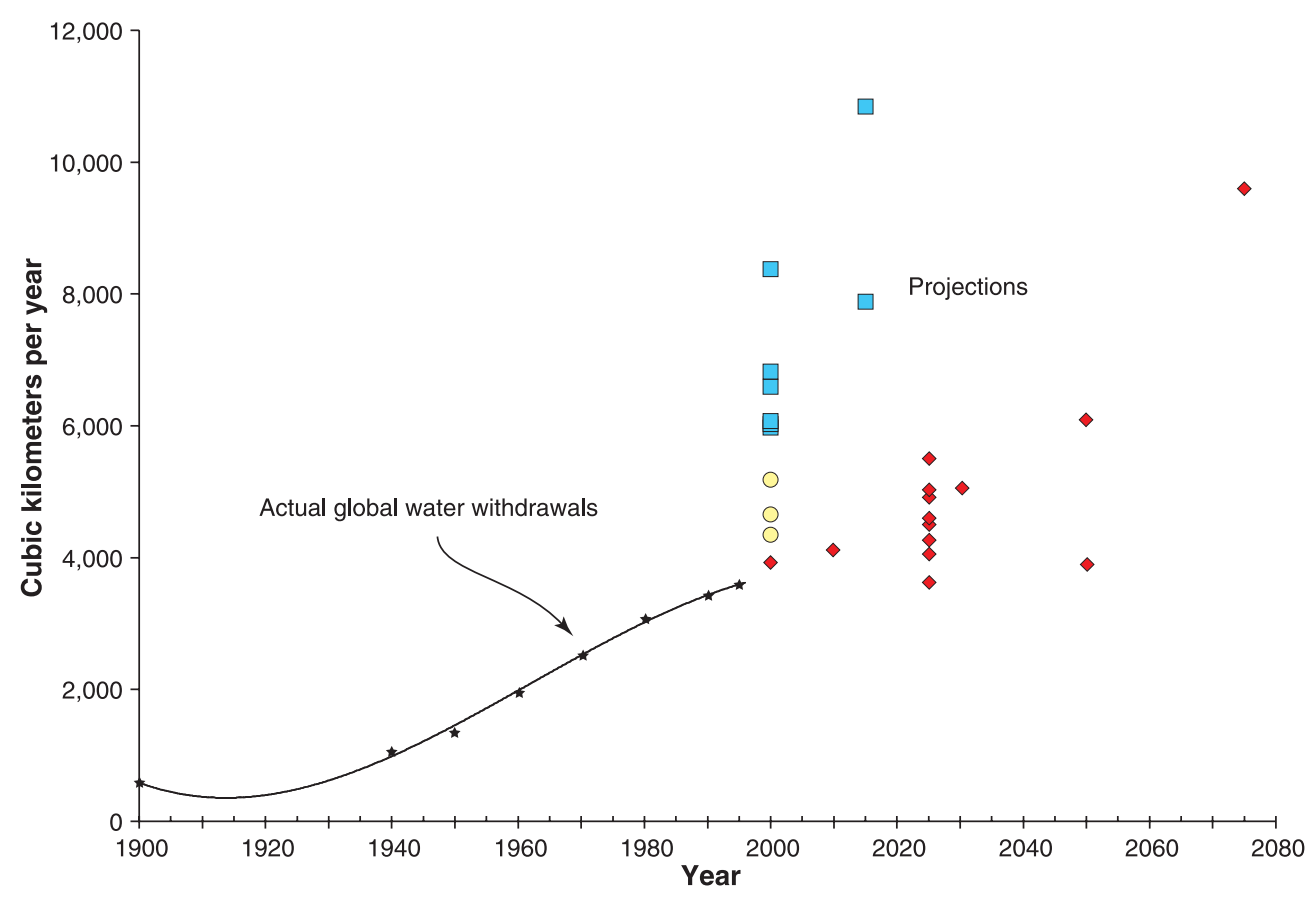

Fig. 3. Projections of water use and actual global water withdrawals, as compiled from various projections of global water withdrawals made since the 1960s (44), together with an estimate of actual global water withdrawals, as estimated in (45). Note that projections made before 1980 forecast very substantial increases in water use; more recent forecasts have begun to incorporate possible improvements in water productivity to reflect recent historical experience. Symbols: squares, projections made before 1980 (includes forecasts for 2000 or 2015); circles, projections made between 1980 and 1995 (includes forecasts for 2000); diamonds, projections made after 1995 (includes forecasts for 2000, 2010, 2025, 2030, 2050, 


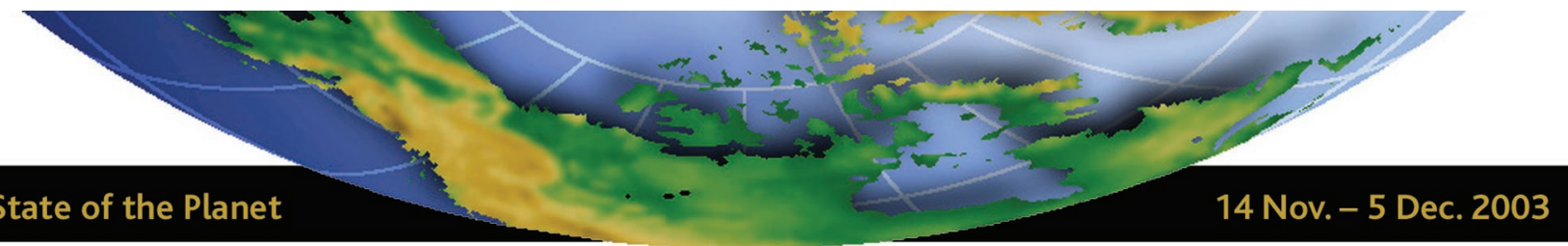

decades of projections shows that planners consistently assumed continued, and even accelerated, exponential growth in total water demand (Fig. 3). Some projections were that water withdrawals would have to triple and even quadruple in coming years, requiring additional dams and diversions on previously untapped water resources in remote or pristine areas once declared off-limits to development. Proposals have been made to flood the Grand Canyon, dam the Amazon, and divert Siberian and Alaskan rivers to southern population centers.

Instead, as Figs. 3 and 4 show, total water withdrawals began to stabilize in the 1970 s and 1980s, and construction activities began to slow as the unquantified but real environmental and social costs of dams began to be recognized. More recently, the economic costs of the traditional hard path have also risen to levels that society now seems unwilling or unable to bear. The most cited estimate of the cost of meeting future infrastructure needs for water is $\$ 180$ billion per year to 2025 for water supply, sanitation, wastewater treatment, agriculture, and environmental protection-a daunting figure, given current levels of spending on water (19). This figure is based on the assumption that future global demand for water and water-related services will reach the level of industrialized nations and that centralized and expensive water supply and treatment infrastructure will have to provide it. If we focus on meeting basic human needs for water for all with appropriate-scale technology, the cost instead could be in the range of $\$ 10$ billion to $\$ 25$ billion per year for the next two decades - a far more achievable level of investment (20). Similarly, as large-infrastructure solutions have become less attractive, new ideas are being developed and tried and some old ideas are being revived, such as rainwater harvesting and integrated land and water management. These alternative approaches must be woven together to offer a comprehensive toolbox of possible solutions.

strives to improve the productivity of water use rather than seek endless sources of new supply. It delivers water services and qualities matched to users' needs, rather than just delivering quantities of water. It applies economic tools such as markets and pricing, but with the goal of encouraging efficient use, equitable distribution of the resource, and sustainable system operation over time. And it includes local communities in decisions about water management, allocation, and use (21-23). As Lovins noted for the energy industry, the industrial dynamics of this approach are very different, the technical risks are smaller, and the dollars risked far fewer than those of the hard path (24).

Rethinking water use means reevaluating the objec-

\section{A New Approach for Water}

What is required is a "soft path," one that continues to rely on carefully planned and managed centralized infrastructure but complements it with small-scale decentralized facilities. The soft path for water tives of using water. Hard-path planners erroneously equate the idea of using less water, or failing to use much more water, with a loss of well-being. This is a fallacy. Soft-path planners believe that people want to satisfy demands for goods and services, such as food, fiber, and

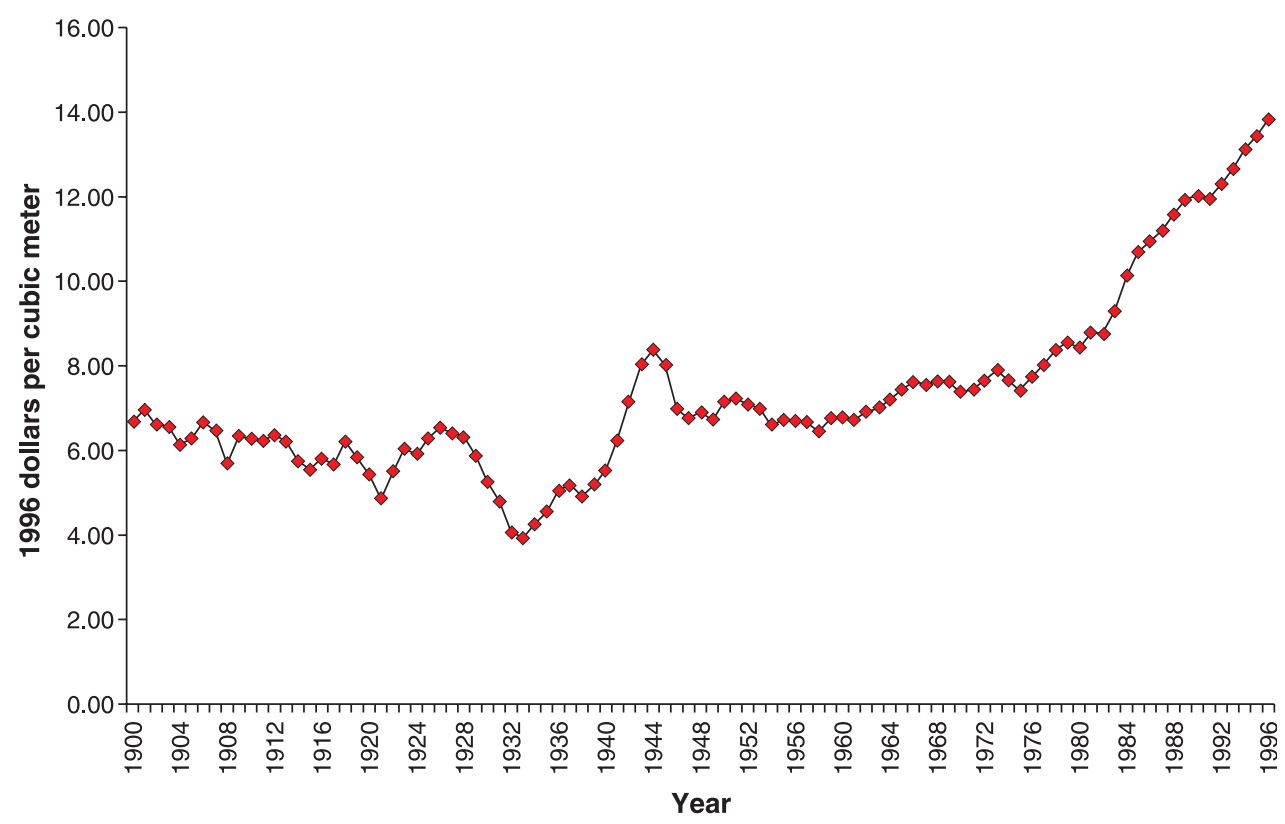

Fig. 5. Economic productivity of water use in the United States, 1900 to 1996 . The economic productivity of water use in the United States, measured as \$GNP (gross national product, corrected for inflation) per cubic meter of water withdrawn, has risen sharply in recent years, from around $\$ 6$ to $\$ 8 / \mathrm{m}^{3}$ to around $\$ 14 / \mathrm{m}^{3}$. Although GNP is an imperfect measure of economic well-being, it provides a consistent way to begin to evaluate the economic productivity of water use. 


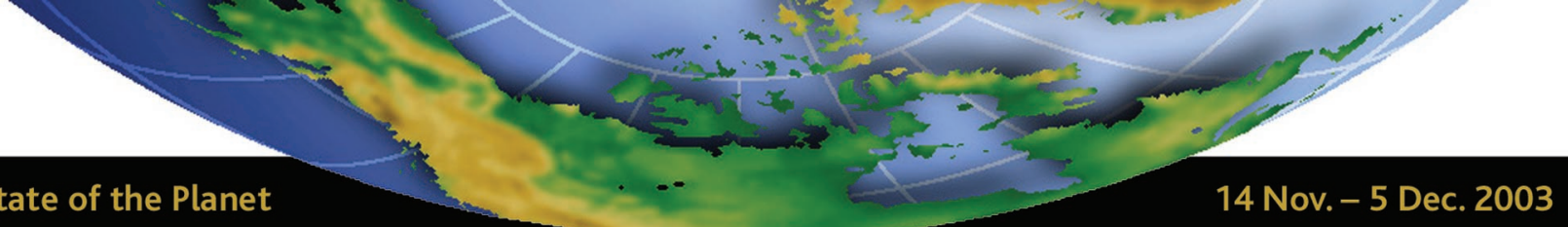

waste disposal, and may not care how much water is used-or even whether water is used at all — as long as these services are produced in convenient, cost-effective, and socially acceptable ways. Thus, society's goal should be not the use of water, but improved social and individual well-being per unit water used.

Waste disposal, for example, does not require any water, although some water for this purpose may be appropriate or desirable for social or cultural reasons. Industrial nations have grown accustomed to water-based sanitation; indeed, in the United States, the largest indoor user of water in homes is the flush toilet, which requires and then contaminates huge volumes of potable water. In the last two decades, however, the amount of water required by toilets in the United States has declined by up to $75 \%$ as new efficiency standards have been adopted (25), and even greater reductions are possible (26).

Another example of one piece of the soft path can be seen in a new study of the potential for water conservation and efficiency improvements in California's urban sector. This analysis shows that the same services now being provided in urban areas, including residential, commercial, and industrial activities, can be provided with $67 \%$ of the water now used for those purposes with current technology at current prices (27).

In the agricultural sector, farmers do not want to use water per se; they want to grow crops profitably. Changing irrigation technology or crop characteristics permits growers to produce more food and fiber per unit water. Efficiency improvements can result from furrow diking, land leveling, direct seeding, drip irrigation, changes in plant varieties, low-energy precisionapplication sprinklers, and simply better information about when and where to irrigate. Drip irrigation and microsprinklers can achieve efficiencies in excess of $95 \%$, compared to flood irrigation efficiencies of $60 \%$ or less (28). As of 2000 , however, the area under micro-irrigation worldwide was less than 3 million hectares, only about $1 \%$ of all irrigated land (29). In China, furrow and flood irrigation was used on $97 \%$ of irrigated land; only $3 \%$ was watered with sprinklers and drip systems (30).

Industrial facilities are also finding new ways to reduce water use and recycle existing withdrawals. The dairy industry in the 1970 s required 3 to 6 liters of process water to make a liter of milk; today, the most efficient dairies use less than 1 liter of water per liter of milk (31). Producing a 200-mm semiconductor silicon wafer used about $30 \mathrm{gal} / \mathrm{in}^{2}$ in 1997 , and this is expected to drop to $6 \mathrm{gal} / \mathrm{in}^{2}$ by the end of 2003 (32).

All of these factors have already begun to lead to substantial improvements in the economic productivity of water use, measured in dollars of economic production per cubic meter of water withdrawn. Figure 5 shows the substantial increase in U.S. economic productivity of water from 1900 to the late 1990s as water use efficiency has improved and as our economy has shifted from water-intensive production. Other countries show similar gains (33). These improvements mean that the United States used less water for all purposes in the late 1990s than it did two decades earlier, despite large increases in our economy and population (34).

Ultimately, meeting basic human and ecological needs for water, improving water quality, eliminating overdraft of groundwater, and reducing the risks of political conflict over shared water require fundamental changes in water management and use. More money and effort should be devoted to providing safe water and sanitation services to those without them, using technologies and policies appropriate to the scale of the problem. Economic tools should be used to encourage efficient use of water and reallocation of water among different users. Ecological water needs should be quantified and guaranteed by local or national laws. And long-term water planning must include all stakeholders, not just those traditionally trained in engineering and hydrologic sciences.

The transition to a comprehensive "soft path" is already under way, but we must move more quickly to address serious unresolved water problems. We cannot follow both paths.

\section{References and Notes}

1. World Commission on Dams, Dams and Development: A New Framework for Decision-Making (Earthscan, London, 2000).

2. A. Ricciardi, J. B. Rasmussen, Conserv. Biol. 13, 1220 (1999).

3. S. Nixon, Ambio 23, 30 (2003).

4. C. J. Vorosmarty, M. Meybeck, in Vegetation, Water, Humans and the Climate, P. Kabat et al., Eds. (Springer-Verlag, Heidelberg, Germany, 2003), pp. 408-572.

5. M. J. Cohen, C. Henges-Jeck, Missing Water: The Uses and Flows of Water in the Colorado River Delta Region (Pacific Institute for Studies in Development, Environment, and Security, Oakland, CA, 2001) (www. pacinst.org/missing_water_report_web.pdf).

6. Several bills were introduced in 2003 in the U.S Congress that call for building new dams, expanding existing dams, or studying new sites for dams in the western United States, including HR 2828, introduced by Rep. Ken Calvert (R-CA), and HR 309, introduced by Rep. Devin Nunes (R-CA).

7. World Health Organization, Global Water Supply and Sanitation Assessment 2000 Report (www.who.int/ docstore/water_sanitation_health/Globassessment/ GlobalTOC.htm)

8. The global population in 1940 was 2.3 billion, as estimated in (35).

9. "Water-related diseases" include waterborne (diarrheas, dysenteries, and enteric fevers), water-washed (including infections skin and eye diseases associated with contaminated water), water-based (including parasitic diseases such as schistosomiasis and dracun- culiasis), and diseases associated with water-based insect vectors (such as malaria, yellow fever, and dengue). The lower death estimates exclude waterbased insect vector diseases. Data on deaths vary; the World Health Organization estimates deaths from diarrheal diseases alone at 2 million to 3 million per year (7).

10. Resolution A/RES/550196, "International Year of Freshwater, 2003" adopted by the UN General Assembly, 1 February 2001.

11. Resolution A/55/L.2, "United Nations Millennium Declaration" adopted by the UN General Assembly, 18 September 2000.

12. P. H. Gleick, Dirty Water: Estimated Deaths from Water-Related Diseases 2000-2020 (Pacific Institute for Studies in Development, Environment, and Security, Oakland, CA, 2002) (www.pacinst.org/reports/ water_related_deaths_report.doc).

13. The estimate for cumulative AIDS deaths over this same period is 68 million (36).

14. Organization for Economic Cooperation and Development, Creditor Reporting System, Aid Activities in the Water Sector: 1997-2002 (OECD, Development Assistance Committee, Paris, 2002).

15. S. Postel, A. Wolf, Foreign Policy (September/October), 60 (2001).

16. J. Burke, M. Moench, Groundwater and Society: Resources, Tensions, Opportunities (United Nations, New York, 2000).

17. Intergovernmental Panel on Climate Change, Climate Change 2001: Impacts, Adaptation, and Vulnerability (Cambridge Univ. Press, Cambridge, 2001), especially the sections on hydrology and water resources.

18. IAHS Ad Hoc Group on Global Water Data Sets, Eos 82 (no. 5), 54 (2001).

19. Costs for major hydropower dams or large-scale water transfers are not included in this already large number (37).

20. The more expensive estimates assume a cost of around $\$ 500$ per person-typical of the costs of centralized water systems in developed countries. However, field experience shows that safe and reliable water supply and sanitation services can be provided in urban areas for $\$ 35$ to 50 per person and in rural areas for less than that when local communities build appropriate-scale technology (38).

21. P. H. Gleick, Nature 418, 373 (2002).

22. G. Wolff, P. H. Gleick, in The World's Water 20022003, P. H. Gleick, Ed. (Island, Washington, DC, 2002), pp. 1-32.

23. D. Brooks, Another Path Not Taken: A Methodological Exploration of Water Soft Paths for Canada and Elsewhere (Friends of the Earth, Ottawa, Canada, 2003).

24. Lovins is to be credited with coining the term "soft path" for energy (39).

25. National Energy Policy Act of 1992, Public Law 102486, 24 October 1992

26. Dual-flush toilets that use only 60 to $70 \%$ of the water used by toilets that meet current U.S. standards are widely used in Australia and Japan.

27. P. H. Gleick et al., Waste Not, Want Not: The Potential for Urban Water Conservation in California (Pacific Institute for Studies in Development, Environment, and Security, Oakland, CA, in press).

28. A. L. Vickers, Handbook of Water Use and Conservation (WaterPlow, Amherst, MA, 2001).

29. S. Postel, Pillar of Sand: Can the Irrigation Miracle Last? (Norton, New York, 1999).

30. L. Jin, W. Young, Water Policy 3, 215 (2001).

31. Water Efficiency Manual (North Carolina Division of Pollution Prevention and Environmental Assistance, 1998) (www.p2pays.org/ref/01/0069206.pdf).

32. In the semiconductor industry, gallons per square inch $\left(\mathrm{g} / \mathrm{in}^{2}\right)$ is the standard metric of measuring water use; $1 \mathrm{~g} / \mathrm{in}^{2}$ is equal to 0.59 liters $/ \mathrm{cm}^{2}(40,41)$.

33. P. H. Gleick, Annu. Rev. Environ. Resour., in press.

34. As of the date of preparation of this article, the data for 2000 were still not available. See (42) for data from the 1990s. 


\section{State of the Planet}

\section{Nov. - 5 Dec. 2003}

35. World Population Prospects as Assessed in 1963 (United Nations, New York, 1966).

36. UNAIDS, Report on the Global HIVIAIDS Epidemic, UNAIDS/02.26.E (Geneva, Switzerland, 2002).

37. W. Cosgrove, F. Rijsberman, A Water Secure World: Report of the World Commission for Water in the 21st Century. Chapter 4: Framework for Action (World Water Council, London, 2000) (www.worldwatercouncil.org/Vision/ Documents/CommissionReport.pdf).

38. Water Supply and Sanitation Collaborative Council, Vision 21: A Shared Vision for Hygiene, Sanitation, and Water Supply (2000) (www.worldwatercouncil. org/Vision/Documents/VISION21FinalDraft.PDF).
39. A. Lovins, Soft Energy Paths: Toward a Durable Peace (Ballinger, Cambridge, MA, 1977).

40. International Technology Roadmap for Semiconductors, 2001 Edition (http://public.itrs.net/Files/ 2001ITRS/Home.htm).

41. S. Allen, M. R. Hahn, Semiconductor Wastewater Treatment and Reuse. Semiconductor Fab Tech (Microbar Inc., Sunnyvale, CA, ed. 9, 1999).

42. W. B. Solley, R. R. Pierce, H. A. Perlman, Estimated Use of Water in the United States, 1995 (USGS Circular 1200, U.S. Geological Survey, Denver, CO, 1998).

43. P. H. Gleick, in The World's Water 2000-2001, P. H. Gleick, Ed. (Island, Washington, DC, 2000), pp. 39-61.
44. For a summary of global water scenarios and a complete list of the scenarios and projections used in this figure, see (43).

45. I. A. Shiklomanov, Assessment of Water Resources and Water Availability in the World. United Nations Report for the Comprehensive Assessment of the Freshwater Resources of the World, Data archive, CD-ROM from the State Hydrologic Institute of St. Petersburg, Russia (1998).

46. A. B. Avakyan, V. B. lakovleva, Lakes Reservoirs Res. Manage. 3, 45 (1998)

Web Resources

www.sciencemag.org/cgi/content/full/302/5650/1524/DC1 